Effects of high $\mathrm{CO}_{2}$ seawater on the copepod (Acartia tsuensis) through all life

\title{
stages and subsequent generations
}

Haruko Kurihara* and Atsushi Ishimatsu

Institute for East China Sea Research, Nagasaki University, 1551-7 Tairamachi,

Nagasaki, 851-2213, Japan

Corresponding author:

Haruko Kurihara

E-mail: harukoku@e-mail.jp

Mailing address: Institute for East China Sea Research, Nagasaki University, 1551-7

Tairamachi, Nagasaki, 851-2213, Japan

Key words. $\mathrm{CO}_{2}$, decreased $\mathrm{pH}$, ocean acidification, copepod, all life stages, reproduction 


\section{Abstract}

We studied the effects of exposure to seawater equilibrated with $\mathrm{CO}_{2}$-enriched air $\left(\mathrm{CO}_{2}\right.$

2,380 ppm) from eggs to maturity and over 2 subsequent generations on the copepod

Acartia tsuensis. Compared to the control $\left(\mathrm{CO}_{2} 380 \mathrm{ppm}\right)$, high $\mathrm{CO}_{2}$ exposure through

all life stages of the $1^{\text {st }}$ generation copepods did not significantly affect survival, body

size or developmental speed. Egg production and hatching rates were also not

significantly different between the initial generation of females exposed to high $\mathrm{CO}_{2}$

and the $1^{\text {st }}$ and $2^{\text {nd }}$ generation females developed from eggs to maturity in high $\mathrm{CO}_{2}$.

Thus, the copepods appear more tolerant to increased $\mathrm{CO}_{2}$ than other marine organisms

previously investigated for $\mathrm{CO}_{2}$ tolerance (i.e. sea urchins and bivalves). However, the crucial importance of copepods in marine ecosystems requires thorough evaluation of the overall impacts of marine environmental changes predicted to occur with increased $\mathrm{CO}_{2}$ concentrations, i.e., increased temperature, enhanced UV irradiation, and changes in the community structure and nutritional value of phytoplankton. 


\section{Introduction}

The recent report from the Intergovernmental Panel on Climate Change (IPCC) pointed out that warming of the climate system is unequivocal, and that most of the warming is very likely due to the increase in anthropogenic green-house gas concentrations, of which carbon dioxide $\left(\mathrm{CO}_{2}\right)$ is the most important (IPCC, 2007). The present atmospheric $\mathrm{CO}_{2}$ concentration (380 ppm) has already risen by 100 ppm since the pre-industrial level, and exceeds by far the natural range over the past 650,000 years (IPCC, 2007). Increased atmospheric $\mathrm{CO}_{2}$ diffuses into the ocean surface waters and lowers the $\mathrm{pH}$; the present surface ocean $\mathrm{pH}(8.2)$ is already lower by $0.1 \mathrm{pH}$ unit than pre-industrial values, and is predicted to decrease by 0.77 units along with the elevation of atmospheric $\mathrm{CO}_{2}$ to ca. 2,000 ppm within the next 300 years (Caldeira and Wickett, 2003).

Ocean acidification due to increased $\mathrm{CO}_{2}$ may have profound impacts on marine biota. Although pertinent information is only recently emerging, the most well-understood biological impact of high seawater $\mathrm{CO}_{2}$ is the reduction of the calcification rate in calcifying organisms due to acidification-driven lowering of the 
calcium carbonate $\left(\mathrm{CaCO}_{3}\right)$ saturation state (Feely et al., 2004; Langdon and Atkinson, 2005; Raven et al., 2005; Kleypas et al., 2006). Recent studies, however, have revealed that long-term hypercapnia could disrupt the physiology of exposed marine organisms. For example, three-month exposure to hypercapnic seawater ( $\mathrm{pH}$ 7.3) reduced both growth and oxygen consumption in marine mussels Mytilus galloprovincialis (Michaelidis et al., 2005). Changes in metabolic enzyme activities and a transient acid-base disturbance were reported for the teleost Sparus aurata exposed to seawater acidified to $\mathrm{pH} 7.3$ by adding $\mathrm{CO}_{2}$ for 10 days (Michaelidis et al. 2007). These two studies used $\mathrm{CO}_{2}$ to acidify test seawater, but did not report $\mathrm{CO}_{2}$ partial pressure $\left(\mathrm{pCO}_{2}\right)$ of the seawater. In addition, early development was shown to be disturbed by exposure to high ambient $\mathrm{CO}_{2}$. Kurihara and Shirayama (2004) demonstrated that $\mathrm{CO}_{2}$ reduces fertilization, cleavage, developmental speed and pluteus larval size of the sea urchins Hemicentrotus pulcherrimus and Echinometra mathaei in a concentration-dependent manner. More recently, Kurihara et al. (2007) reported that exposure to 2,268 ppm $\mathrm{CO}_{2}$ conditions ( $\mathrm{pH}$ 7.4) leads to significant disruption of shell formation and considerable tetrogenesis in the oyster Crassostrea gigas. Reduced metabolic rates and growth could 
be fatal for organisms if such conditions occur over a prolonged period. Effects on early development and reproduction would lead to a reduction of community size if they continue over generations. On the other hand, there is a possibility that marine organisms will adapt to persistent high $\mathrm{CO}_{2}$ environment such that they resume environmental fitness to proliferate. However, to our knowledge, there has been no study that investigated the effects of increased $\mathrm{CO}_{2}$ conditions over a full life cycle and subsequent generations for metazoan organisms.

In the present study, we first examined the effects of exposure to seawater equilibrated with $\mathrm{CO}_{2}$-enriched air (2,000 ppm above ambient air $\left(\mathrm{CO}_{2} 380 \mathrm{ppm}\right)$, hereafter as $+2,000 \mathrm{ppm}$ ) through all life stages, i.e., from eggs to maturity, on the copepod Acartia tsuensis to compare survival, body size and developmental speed. We then compared egg production and hatching rate between the initial generation of females exposed to high $\mathrm{CO}_{2}$ and the $1^{\text {st }}$ and $2^{\text {nd }}$ generation females that had developed from eggs to maturity in high $\mathrm{CO}_{2}$ conditions. Planktonic copepods constitute the bulk of the biomass in most pelagic zooplanktonic communities and are important food source for higher trophic organisms including krill and fishes (Nybakken, 2001). 
Therefore, evaluating the impacts of increased $\mathrm{CO}_{2}$ on copepods is essential for projecting possible alterations of marine ecosystems in future acidified oceans. We selected $A$. tsuensis as our experimental material because it has a short life cycle (they develop from eggs to adults in 9 days at $25^{\circ} \mathrm{C}$ ) and is readily reared over several generations under laboratory conditions.

\section{Material and methods}

\subsection{Test animals}

Adults of Acartia tsuensis used in this study were obtained from stock

cultures that have been reared for ca. 1 year in our laboratory. The copepods were kept in 5-L plastic beakers filled with filtered (GF/C $1.2 \mu \mathrm{m})$ and sterilized $\left(121^{\circ} \mathrm{C}, 15 \mathrm{~min}\right)$ seawater (FSW) at $25^{\circ} \mathrm{C}$ and under $24 \mathrm{~h}$ light conditions, and fed on a mixture of three phytoplankton species, Isochrysis galbana, Chaetoceros gracilis and Pavlova lutheri. The seawater $\mathrm{pH}$ of the stock beakers ranged between 8.0 and 8.2. 


\subsection{Seawater preparation}

Control seawater was prepared by aerating FSW enriched with $5 \times 10^{5}$ cells

$\mathrm{mL}^{-1}$ of I. galbana, with air $\left(\mathrm{CO}_{2}\right.$ concentration: $\left.380 \mathrm{ppm}\right)$. Seawater of higher $\mathrm{CO}_{2}$ concentration was bubbled with $\mathrm{CO}_{2}$-enriched air of which the $\mathrm{CO}_{2}$ concentration was adjusted to 2,000 ppm above the control concentration $(+2,000 \mathrm{ppm}$, hereafter referred to as $\mathrm{CO}_{2}$ seawater). The $\mathrm{CO}_{2}$-enriched air was prepared by mixing air and pure $\mathrm{CO}_{2}$ at flow rates of $500 \mathrm{~mL} \mathrm{~min}{ }^{-1}$ and $1.0 \mathrm{~mL} \mathrm{~min}^{-1}$, respectively, using a flow meter (Kofloc 250, Japan). The seawater salinity (35) was measured with a refractometer (Atago, 100-S, Japan).

\subsection{Survival and growth rate}

Approximately 200 adult individuals of both sexes were divided into 2 groups and reared for $24 \mathrm{~h}$ in two beakers (capacity $1 \mathrm{~L}$ ), each containing $1 \mathrm{~L}$ of control (380 
ppm) or $\mathrm{CO}_{2}$ seawater. Cultures were continuously aerated in an incubator at $25 \pm 1^{\circ} \mathrm{C}$ and under $24 \mathrm{~h}$ dark conditions. The seawater $\mathrm{pH}$ was checked at $0 \mathrm{~h}$ (control: $\mathrm{pH} 8.23$ \pm 0.01 (SD), $\mathrm{CO}_{2}: \mathrm{pH} 7.31 \pm 0.02$ ) and at $24 \mathrm{~h}$ of rearing (control: $\mathrm{pH} 8.18 \pm 0.02, \mathrm{CO}_{2}$ : pH $7.31 \pm 0.01$ ). After $24 \mathrm{~h}$, produced eggs that had been dispersed directly into the seawater were collected from each beaker by filtering (mesh size $300 \mu \mathrm{m}$ ) the seawater to separate females, and 100 eggs were transferred into each of eight $500 \mathrm{~mL}$ Erlenmeyer flasks filled with the control or $\mathrm{CO}_{2}$ seawater. All flasks were continuously bubbled with air or $\mathrm{CO}_{2}$-enriched air at a flow rate of $10 \mathrm{~mL} \mathrm{~min}^{-1}$ in the incubator. The seawater in the flasks was fully renewed once a day to restore the I. galbana concentration to the predetermined level $\left(5 \times 10^{5}\right.$ cells $\left.\mathrm{mL}^{-1}\right)$. The seawater $\mathrm{pH}$ was measured daily before and after renewing the seawater with a pH meter (Mettler Toledo, MP125, USA). The $\mathrm{pH}$ values of the control and $\mathrm{CO}_{2}$ seawater were $8.17 \pm 0.04$ and $7.32 \pm 0.01$, respectively, and remained stable throughout the experiments. On days 3 , 5, 7 and 9, one flask from each experimental group was randomly selected to count the number of individuals therein and classify the developmental stages after fixation (see 
Takahashi and Ohno, 1996 for criteria used for staging). Four replicate experiments were conducted.

\subsection{Egg production and hatching rate of generation 0,1 and 2 females $r$ eared in}

\section{high $\mathrm{CO}_{2}$ seawater}

Ten adult females were collected from the stock cultures, and transferred

individually into $50 \mathrm{~mL}$ vials. The vials were filled with the control or $\mathrm{CO}_{2}$ seawater and stoppered leaving no air space, and kept in dark conditions at $25^{\circ} \mathrm{C}$ (generation 0 ). To prevent egg consumption by the females, the seawater was enriched with enough food $\left(5 \times 10^{5}\right.$ cells $\mathrm{mL}^{-1}$ I. galbana). After $24 \mathrm{~h}$, the number of eggs produced from each female was counted. Ten eggs were transferred into another set of $50 \mathrm{~mL}$ vials filled with the control or $\mathrm{CO}_{2}$ seawater. After a further $24 \mathrm{~h}$ in the same conditions, hatching rate was estimated by counting the number of egg's shells in the 10 eggs. The seawater $\mathrm{pH}$ remained stable during the $24 \mathrm{~h}$ incubation. To study the egg production ability and egg hatchability of females developed from eggs in the high $\mathrm{CO}_{2}$ conditions (generation 
1), a sufficiently large number of both adult males and females were reared in $1 \mathrm{~L}$ flasks

bubbled with air or $\mathrm{CO}_{2}$-enriched air at a flow rate of $20 \mathrm{~mL} \mathrm{~min}^{-1}$, and produced eggs were collected $24 \mathrm{~h}$ afterwards. These eggs were transferred into other $1 \mathrm{~L}$ flasks aerated in the same manner, and reared for ca. 10 days until they developed into the adult stage. Ten females were randomly selected and reared individually to study egg production ability and egg hatchability as for the generation 0 females. The same procedure was repeated to obtain data for the generation 2 females. When no eggs from a female hatched in $24 \mathrm{~h}$, the female was considered not to have copulated, and the data not included in the analysis. Seawater $\mathrm{pH}$ was measured at the beginning and termination of each experiment to verify that $\mathrm{pH}$ had not changed during the experiments. The $\mathrm{pH}$ values of the control and $\mathrm{CO}_{2}$ seawater were $8.14 \pm 0.06$ and $7.32 \pm 0.04$, respectively.

\subsection{Statistical analysis}

Treatment effects on survival, egg production and hatching rate were tested for significance at the 5\% level using two-way ANOVA. When there was a significant difference between the groups using two-way ANOVA, Student t-test was applied. 
Student t-test was used to analyze effects on promosome length of different stages.

Values are presented as the mean \pm SD throughout.

\section{Results}

Survival was not significantly different between the copepods reared in the control and $\mathrm{CO}_{2}$ seawater from eggs to the adult stage (Fig. 1, two-way ANOVA). The overall averages of survival rates were $53 \%$ and $43 \%$ for the control and the $\mathrm{CO}_{2}$ copepods, respectively, and there was no significant difference in survival with time (Fig. 1, two-way ANOVA). The sex ratio did not also differ between the groups (female $40 \pm 4.7 \%$ (control) and $45 \pm 8.3 \%\left(\mathrm{CO}_{2}\right)$ ).

Figure 2 compares developmental stages of the control and $\mathrm{CO}_{2}$ group on 3, 5, 7 and 9 days after culture. By day 3, all eggs had developed into nauplii with nauplius stage 4 (N4) comprising ca. $60 \%$ of the total copepods in both groups. By day 5 , half of the copepods had developed into the copepodite stage, and by day 7, most copepods had developed into the copepodid stage 3 or 4 (C3/C4). Adult copepods (C6) first appeared 
on day 9, and egg production began on day 11 in both groups. There was no difference in the promosome length in all stages between the control and $\mathrm{CO}_{2}$ copepods (Fig. 3, t-test).

The overall egg production rates did not differ between the control and $\mathrm{CO}_{2}$ copepods (Fig. 4, two-way ANOVA), although there was a significant difference between generations (Fig. 4, $P<0.05$, two-way ANOVA). The overall hatching rate of $\mathrm{CO}_{2}$ eggs was significantly lower than that of the control eggs (Fig. 5, $P<0.05$, two-way ANOVA) however there was no significant difference in the hatching rate between the control and $\mathrm{CO}_{2}$ eggs when compared separately for each generation (Fig. 5, t-test).

\section{Discussion}

The present study revealed that exposure to seawater equilibrated with high $\mathrm{CO}_{2}(+2,000 \mathrm{ppm})$ air did not significantly affect the survival rate of the copepod $A$. tsuensis (Fig. 1). The initial reductions of survival seen in both the control and $\mathrm{CO}_{2}$ 
groups by day 3 (Fig. 1) agree with the previous findings of $40 \%$ mortality during the nauplius stages 1 to 3 (Takahashi and Ohno, 1996). Takahashi and Ohno (1996) suggested that the high mortality rate during early stages of the nauplii was due to the difficulty in shifting energy source from yolk-related endogenous food to an exogenous one. Our previous study also demonstrated that the survival of adult A. erythraea and $A$. steueri was unaffected even in seawater equilibrated with $+10,000 \mathrm{ppm} \mathrm{CO}_{2}$ in air $(\mathrm{pH}$ 6.8; Kurihara et al., 2004). Survival of A. erythraea nauplii was unaffected when reared in seawater equilibrated with $+2,000 \mathrm{ppm} \mathrm{CO}_{2}$, but depressed above $+5,000 \mathrm{ppm}$ (Kurihara et al., 2004). Yamada and Ikeda (1999) found a progressive increase in LC 50 and $\mathrm{LC}_{0}$ with increasing exposure time to acidified ( $\left.\mathrm{pH} 7.2-4.5\right)$ seawater by mineral acids for six copepod species. Thus, short-term exposure to $\mathrm{CO}_{2}$ concentration lower than ca. 2,000 ppm, the maximum atmospheric $\mathrm{CO}_{2}$ concentration predicted to occur by the year 2300 (Caldeira and Wickett, 2003), may not reduce, but exposure to higher $\mathrm{CO}_{2}$ concentrations does reduce survival of copepods.

Development of copepods was unaffected by the $\mathrm{CO}_{2}$ treatment at all stages (Figs. 2 and 3). Egg production and hatching rates were also unaffected even when adult 
females were reared for 2 generations in the $\mathrm{CO}_{2}$ seawater (Figs. 4 and 5). Meanwhile, egg production and hatching rates of the two species of copepods, A. steueri and $A$. erythraea, were decreased in a concentration-dependent manner, though effect was significant only above $+5,000$ ppm $\mathrm{CO}_{2}$ (Kurihara et al., 2004). Mayor et al. (2007) demonstrated that exposure to seawater acidified by equilibrating with $8,000 \mathrm{ppm} \mathrm{CO}_{2}$ in air did not affect both growth and egg production of the copepod Calanus finmarchicus, but significantly reduced egg hatching rate. Again, these results indicate that $\mathrm{CO}_{2}$ concentrations higher than ca. 2,000 ppm potentially have negative impacts on reproduction of copepods, while lower concentrations appear not to have significant impact.

In contrast to the present results for copepods, early development was severely impacted in the sea urchins Hemicentrotus pulcherrimus and Echinometra mathaei $\left(\mathrm{CO}_{2}\right.$ concentration $+500-+2000$ ppm, Kurihara and Shirayama, 2004) and in the oyster Crassostrea gigas (2,268 ppm, Kurihara et al., 2007). The two studies demonstrated that synthesis of $\mathrm{CaCO}_{3}$ exoskeleton was disrupted and that most larvae became morphologically abnormal to the extent that they would not probably survive. 
These findings suggest that the projected high $\mathrm{CO}_{2}$ conditions in neritic oceans may alter marine ecosystem structure through different vulnerability of marine organisms to $\mathrm{CO}_{2}$. In addition, fishes are in general far more tolerant to high $\mathrm{CO}_{2}$ than invertebrates, which may lead to restructuring of marine ecosystems through increased predation pressure (Ishimatsu et al., 2005).

Despite seemingly higher $\mathrm{CO}_{2}$ tolerance of copepods than other marine invertebrates, the ecological importance of copepods in the marine ecosystem requires more careful and extensive evaluation of overall impacts of marine environmental changes that are predicted to occur with increased $\mathrm{CO}_{2}$ concentrations. Of particular importance are potential synergistic effects of ocean acidification and other abiotic changes associated with climate change. These include increases in seawater temperature, increased irradiance of ultraviolet light, and changes in salinity (IPCC, 2007). Moreover, some anthropogenically induced factors such as anoxia and high heavy metal concentrations may compound impacts of ocean acidification (Harley et al., 2006). Indeed, Invidia et al. (2004) reported that egg production of A. tonsa was significantly depressed by anoxia at low $\mathrm{pH}$ (pH 6.5). Furthermore, indirect effects 
through altered food-web structures are also likely. Several studies showed that the $\mathrm{C}$ :

$\mathrm{N}$ : P ratio of phytoplankton, which determines the food quality for herbivores (Anderson and Hessen, 1995), changes with increased seawater $\mathrm{CO}_{2}$ (Burkhardt and Riebesell 1997; Burkhardt et al., 1999; Wolf-Gladrow et al., 1999). Wolf-Gladrow et al. (1999) demonstrated that the C : P ratio of the marine diatoms, Skeletonema costatum, Asterionella gracilis and Coscinodiscus wailesii increased with increasing seawater $\mathrm{CO}_{2}$ concentration. Urabe et al. (2003) demonstrated that the $\mathrm{C}: \mathrm{P}$ ratio of freshwater algae increased when cultured under elevated $\mathrm{CO}_{2}$ levels, which led to suppressed growth of Daphnia feeding on them. In addition, species compositions of phytoplankton may also be altered by reduced pH (Hinga, 2002; Tortell et al., 2002). The above are only a few examples that need to be scrutinized, and much more must be understood to accurately predict the fate of marine copepod community in future oceans.

\section{Acknowledgments}

We thank Dr. Atsushi Hagiwara, Nagasaki University and Dr. Takashi Ishimaru, Tokyo University of Marine Science and Technology for providing the copepods, and Dr. 
Mitsunori Iwataki, Nagasaki University for providing the phytoplankton. This study was partially supported by a Grant-in-Aid for Scientific Research from the Japan Society for Promotion of Science (JSPS, 18510011).

\section{References}

Anderson, T.R., Hessen, D.O. 1995. Carbon or nitrogen limitation in marine copepods? Journal of Plankton Research 17, 317-331.

Burkhardt, S., Riebesell, U. 1997. $\mathrm{CO}_{2}$ availability affects elemental composition (C : $\mathrm{N}$ : P) of the marine diatom Skeletonema costatum. Marine Ecology Progress Series 155, 67-76.

Burkhardt, S., Zondervan, I., Riebesell, U. 1999. Effect of $\mathrm{CO}_{2}$ concentration on C : N : $\mathrm{P}$ ratio in marine phytoplankton: a species comparison. Limnology and Oceanography 44, 683-690.

Caldeira, K., Wickett, M.E. 2003. Anthropogenic carbon and ocean pH. Nature 425, 365.

Feely, R.A., Sabine, C.L., Lee, K., Berelson, W., Kleypas, J., Fabry, V.J., Millero, F.J. 
2004. Impact of anthropogenic $\mathrm{CO}_{2}$ on the $\mathrm{CaCO}_{3}$ system in the oceans. Science 305, 362-366.

Harley, C.D.G, Hughes, A.R., Hultgren, K.M., Miner, B.G., Sorte, C.J.B., Thornber, C.S., Rodriguez, L.F., Tomanek, L., Williams, S.L. 2006. The impacts of climate change in coastal marine system. Ecology Letter 9, 228-241.

Hinga, K.R. 2002. Effects of $\mathrm{pH}$ on coastal marine phytoplankton. Marine Ecology Progress Series 238, 281-300.

Invidia, M., Sei, S., Gorbi, G. 2004. Survival of the copepod Acartia tonsa following egg exposure to near anoxia and to sulfide at different $\mathrm{pH}$ values. Marine Ecology Progress Series 276, 187-196.

IPCC 2007. Climate Change 2007: The physical Science Basis. Contribution of Working Group I to the Fourth Assessment Report of the Intergovernmental Panel on Climate Change [Solomon, S., Qin, D., Manning, M., Chen, Z., Marquis, M., Averyt, K.B., Tignor, M. and Miller, H.L. (eds)]. Cambridge University Press, Cambridge.

Ishimatsu, A., Hayashi, M., Lee, K.-S., Kikkawa, T., Kita, J. 2005. Physiological effects 
on fishes in a high- $\mathrm{CO}_{2}$ world. Journal of Geophysical Research 110, C09S09, doi:10.1029/2004JC002564.

Kleypas, J.A., Feely, R.A., Fabry, V.J., Langdon, C., Sabine, C.L., Robbins, L.L. 2006. Impacts of ocean acidification on coral reefs and other marine calcifiers: A guide for future research, report of a workshop held 18-20 April 2005, St. Peterburg, FL, 88pp.

Kurihara, H., Shirayama, Y. 2004. Effects of increased atmospheric $\mathrm{CO}_{2}$ on sea urchin early development. Marine Ecology Progress Series 274, 161-169.

Kurihara, H., Shimode, S., Shirayama, Y. 2004. Effects of raised $\mathrm{CO}_{2}$ concentration on the egg production rate and early development of two marine copepods (Acartia steueri and Acartia erythraea). Marine Pollution Bulletin 49, 721-727.

Kurihara, H., Kato, S., Ishimatsu, A. 2007. Effects of increased seawater $\mathrm{pCO}_{2}$ on the early development of the oyster Crassostrea gigas. Aquatic Biology 1, 91-98.

Langdon, C., Atkinson, M.J. 2005. Effect of elevated $\mathrm{pCO}_{2}$ on photosynthesis and calcification of corals and interactions with seasonal change in temperature/irradiance and nutrient enrichment. Journal of Geophysical 
Research 1011, C09S07, doi: 10.1029/2002GB001941.

Mayor, D.J., Matthews, C., Cook, K., Zuur, A.F., Hay, S. 2007. $\mathrm{CO}_{2}$-induced acidification affects hatching success in Calanus finmarchicus. Marine Ecology Progress Series 350, 91-97.

Michaelidis, B., Ouzounis, C., Paleras, A., Pörtner, H.O. 2005. Effects of long-term moderate hypercapnia on acid-base balance and growth rate in marine mussels Mytilus galloprovincialis. Marine Ecology Progress Series 293, 109-118.

Michaelidis, B., Spring, A., Pörtner, H.O. 2007. Effects of long-term acclimation to environmental hypercapnia on extracellular acid-base status and metabolic capacity in Mediterranean fish Sparus aurata. Marine Biology 150, 1417-1429.

Nybakken, J.M. 2001. Plankton and Plankton Community. In: Marine Biology: An Ecological Approach, 5 ${ }^{\text {th }}$ Edition, pp. 38-93. Benjamin Cummings, San Francisco.

Raven, J., Caldeira, K., Elderfield, H., Hoegh-Guldberg, O., Liss, P., Riebesell, U., Shepherd, J., Turley, C., Watson, A. 2005. Ocean acidification due to increasing atmospheric carbon dioxide. The Royal Society policy document 12/05. The 
Clyvedon Press, Cardiff.

Takahashi, T., Ohno, A. 1996. The temperature effect on the development of calanoid copepod, Acartia tsuensis, with some comments on morphogenesis. Journal of Ocenography 52, 125-137.

Tortell, P.D., Ditullio, G.R., Sigmann, D.M., Morel, F.M.M. 2002. $\mathrm{CO}_{2}$ effects on taxonomic composition and nutrient utilization in an equatorial Pacific phytoplankton assemblage. Marine Ecology Progress Series 236, 37-43.

Urabe, J., Togari, J., Elser, J.J. 2003. Stoichiometric impacts of increased carbon dioxide on a planktonic herbivore. Global Change Biology 9, 818-825.

Wolf-Gradrow D.A., Riebesell, U., Burkhardt, S., Bijma, J. 1999. Direct effects of $\mathrm{CO}_{2}$ concentration on growth and isotopic composition of marine plankton. Tellus 51B, 461-476.

Yamada, Y., Ikeda, T. 1999. Acute toxicity of lowered pH to some oceanic zooplankton. Plankton Biology and Ecology 46, 62-67. 
Figure Caption

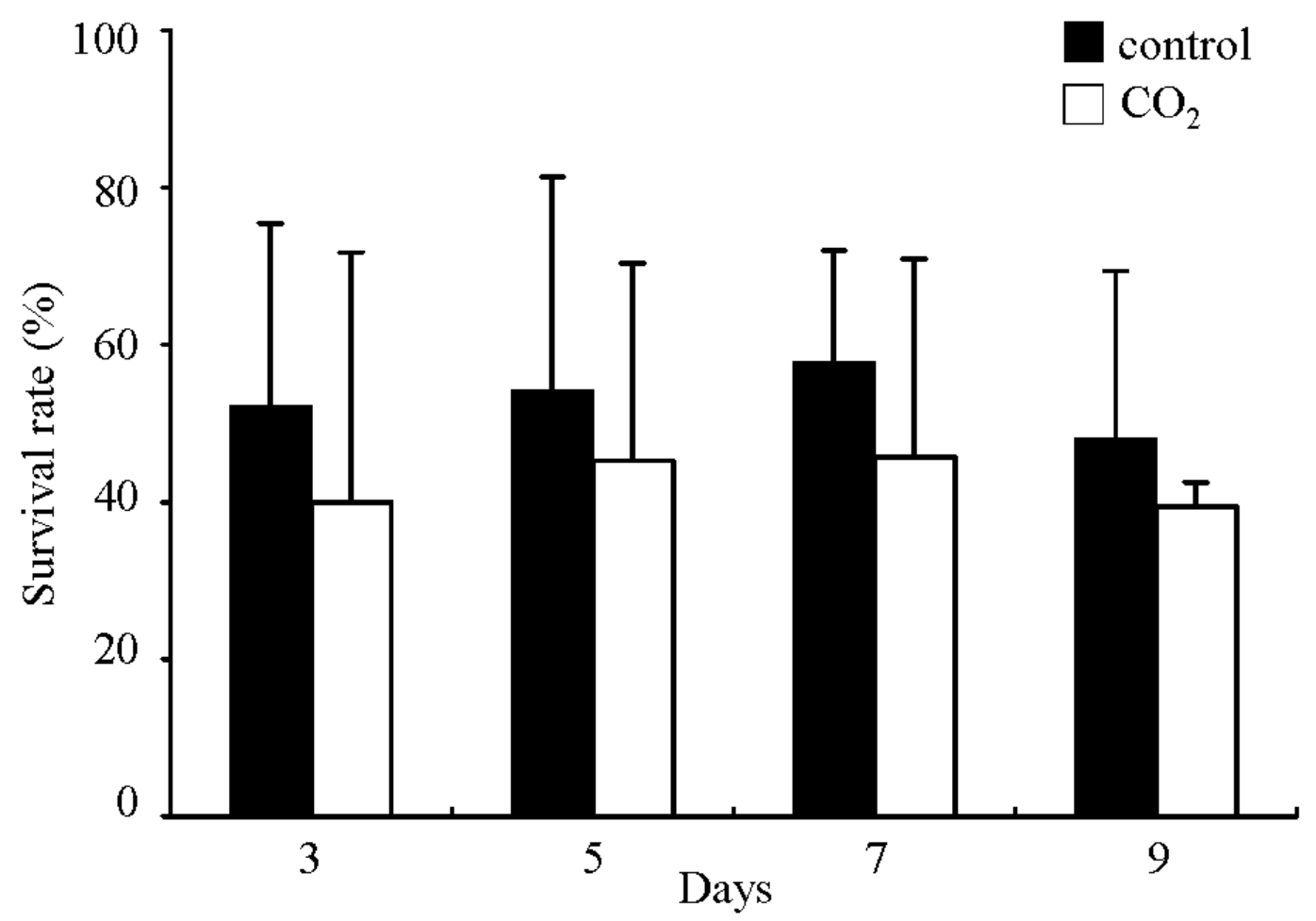

Fig. 1. Survival rate of the Acartia tsuensis eggs reared under control (CO2 380 ppm) and high $\mathrm{CO} 2(+2,000 \mathrm{ppm})$ conditions until they developed into adults over a period of 9 days. There was no significant difference $(P>0.05)$ in the survival rate between the control and CO2 group (two-way ANOVA, P > 0,05). Error bar $=$ SD. $n=4$. 


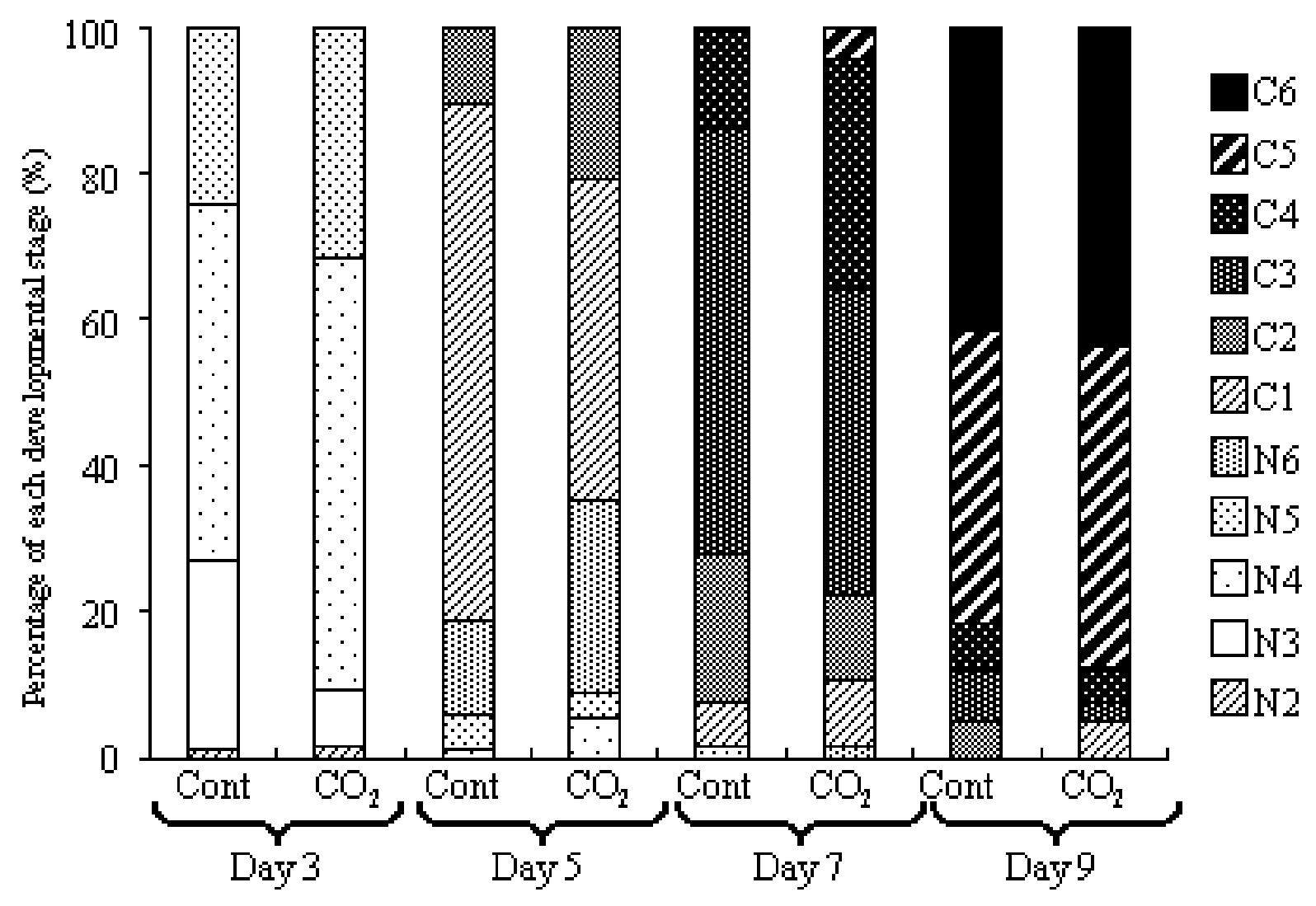

Fig. 2. Percentage of each developmental stage of Acartia tsuensis on 3, 5, 7 and 9 days after hatching from eggs reared under control (CO2 $380 \mathrm{ppm})$ and high $\mathrm{CO} 2(+2,000$ ppm) conditions. Error bar $=$ SD. N2-6: Nauplius stages 2-6, C1-5: Copepodid stages 1-5. C6: Adult 

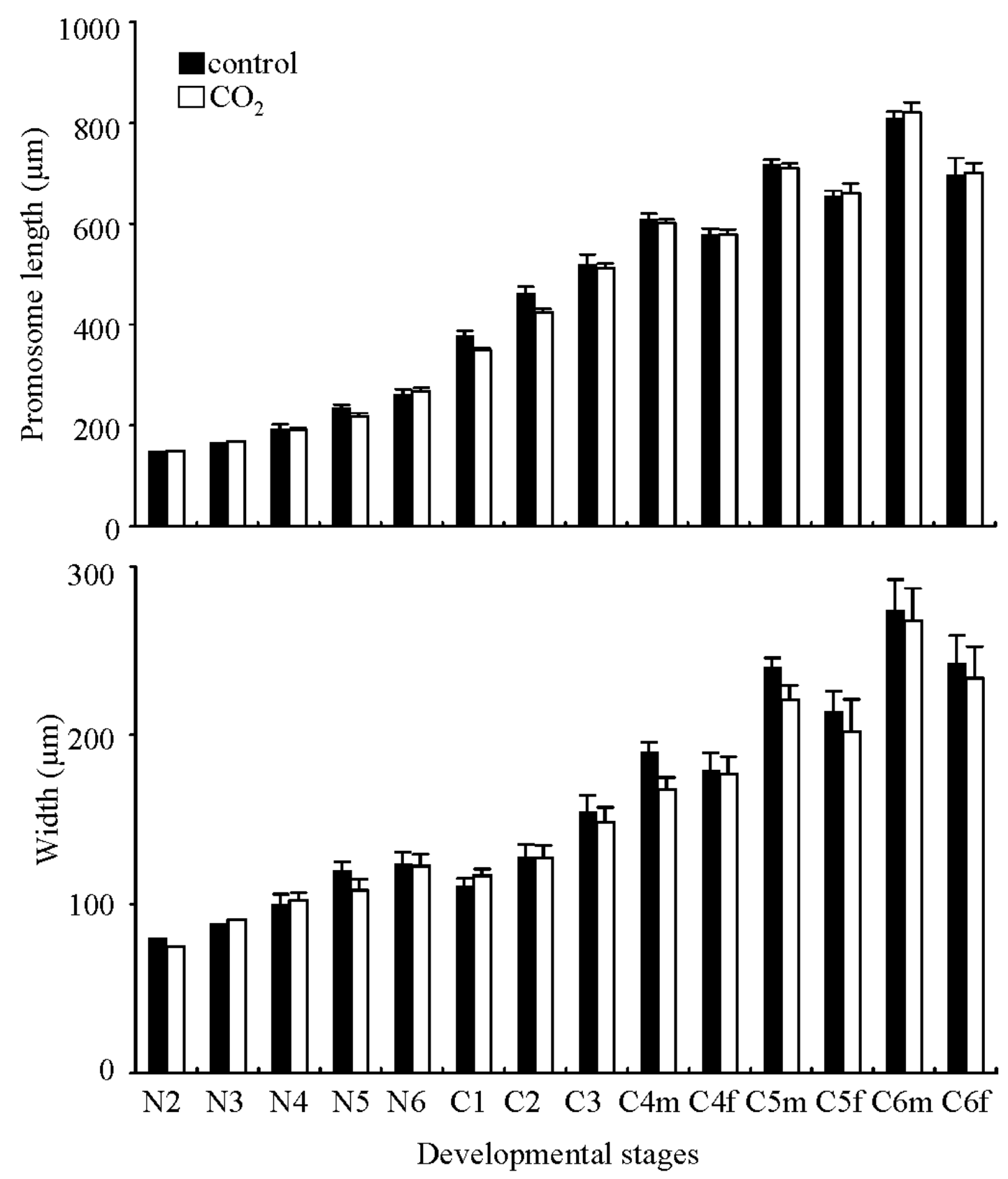

Fig. 3. Promosome length and width of each developmental stage of Acartia tsuensis copepods developed from egg to adult under control (CO2 $380 \mathrm{ppm})$ and high $\mathrm{CO} 2$ $(+2,000 \mathrm{ppm})$ conditions. There was no significant difference in both promosome length and width between the control and $\mathrm{CO} 2$ group (t-test, $\mathrm{P}>0.05$ ). Error bar $=\mathrm{SD}$. N2-6: Nauplius stages 2-6, C1-6: Copepodid stages 1-6, f: Female m: Male. The sex of opepodids becomes identifiable from $\mathrm{C} 4$ by differences in the shape of the urosome and fifth legs. Numbers of individuals measured were: control; N2 $=1, \mathrm{~N} 3=20, \mathrm{~N} 4=39, \mathrm{~N} 5$ $=24, \mathrm{~N} 6=11, \mathrm{C} 1=65, \mathrm{C} 2=25, \mathrm{C} 3=42, \mathrm{C} 4=13, \mathrm{C} 5=24, \mathrm{C} 6=60, \mathrm{CO} 2 ; \mathrm{N} 2=1, \mathrm{~N} 3=6$, $\mathrm{N} 4=48, \mathrm{~N} 5=26, \mathrm{~N} 6=16, \mathrm{C} 1=33, \mathrm{C} 2=20, \mathrm{C} 3=29, \mathrm{C} 4=23, \mathrm{C} 5=21, \mathrm{C} 6=18$. 


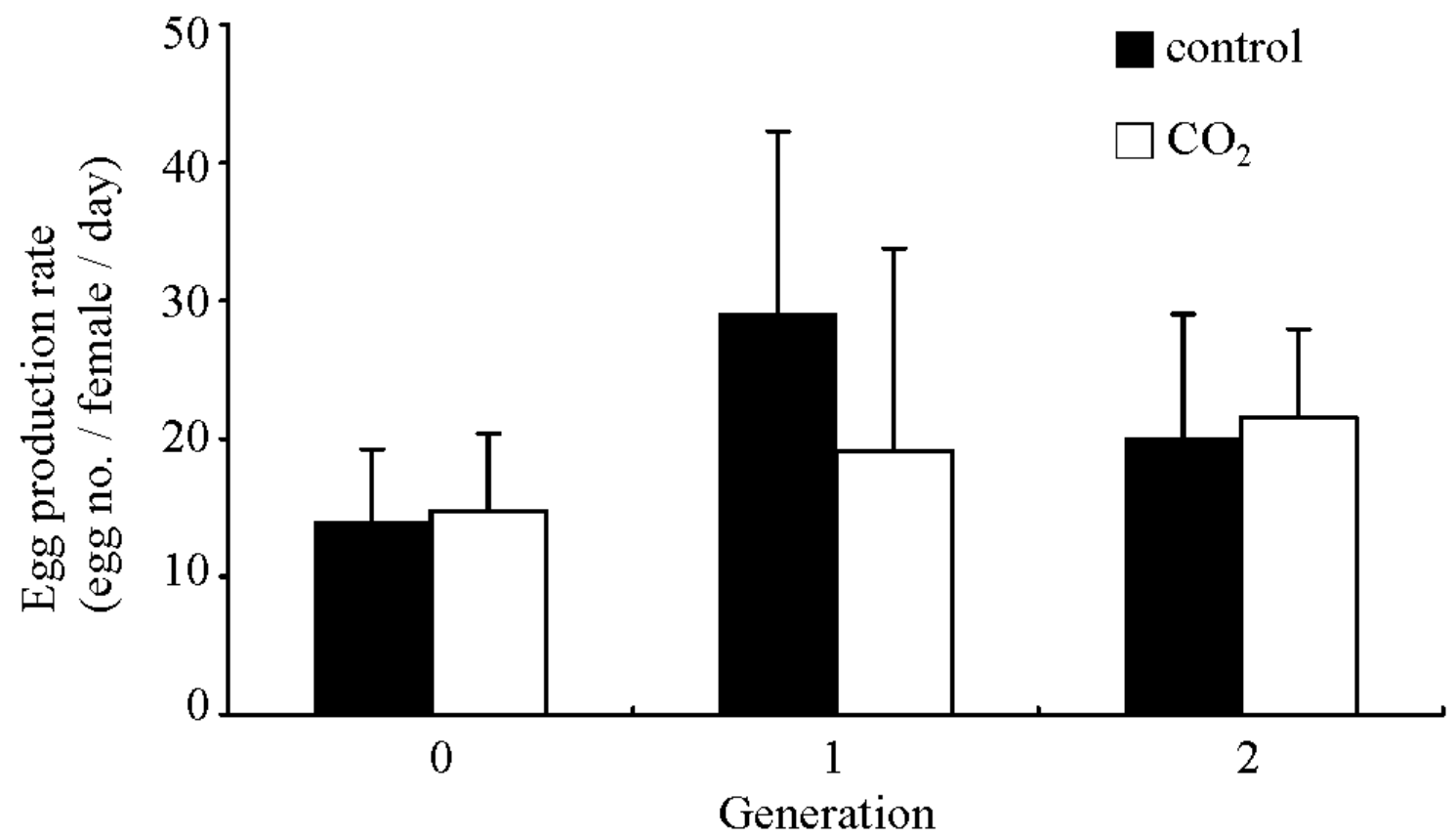

Fig. 4. Egg production rate of female Acartia tsuensis of generations 0,1 and 2. The copepods of generation 0 were those individuals that were reared in control (CO2 380 $\mathrm{ppm})$ or high $\mathrm{CO} 2(+2,000 \mathrm{ppm})$ conditions for $24 \mathrm{~h}$. The copepods of generation 1 were developed in control or $\mathrm{CO} 2$ seawater from egg to adult, and those of generation 2 developed in control or $\mathrm{CO} 2$ seawater conditions into adult from the eggs obtained from the generation 1. There was no difference between control and $\mathrm{CO} 2$ copepods (two-way ANOVA, $\mathrm{P}>0.05$ ), although there was a significant difference between generations (two-way ANOVA, $\mathrm{P}<0.05$ ), Error bar $=\mathrm{SD}, \mathrm{n}=10$. 


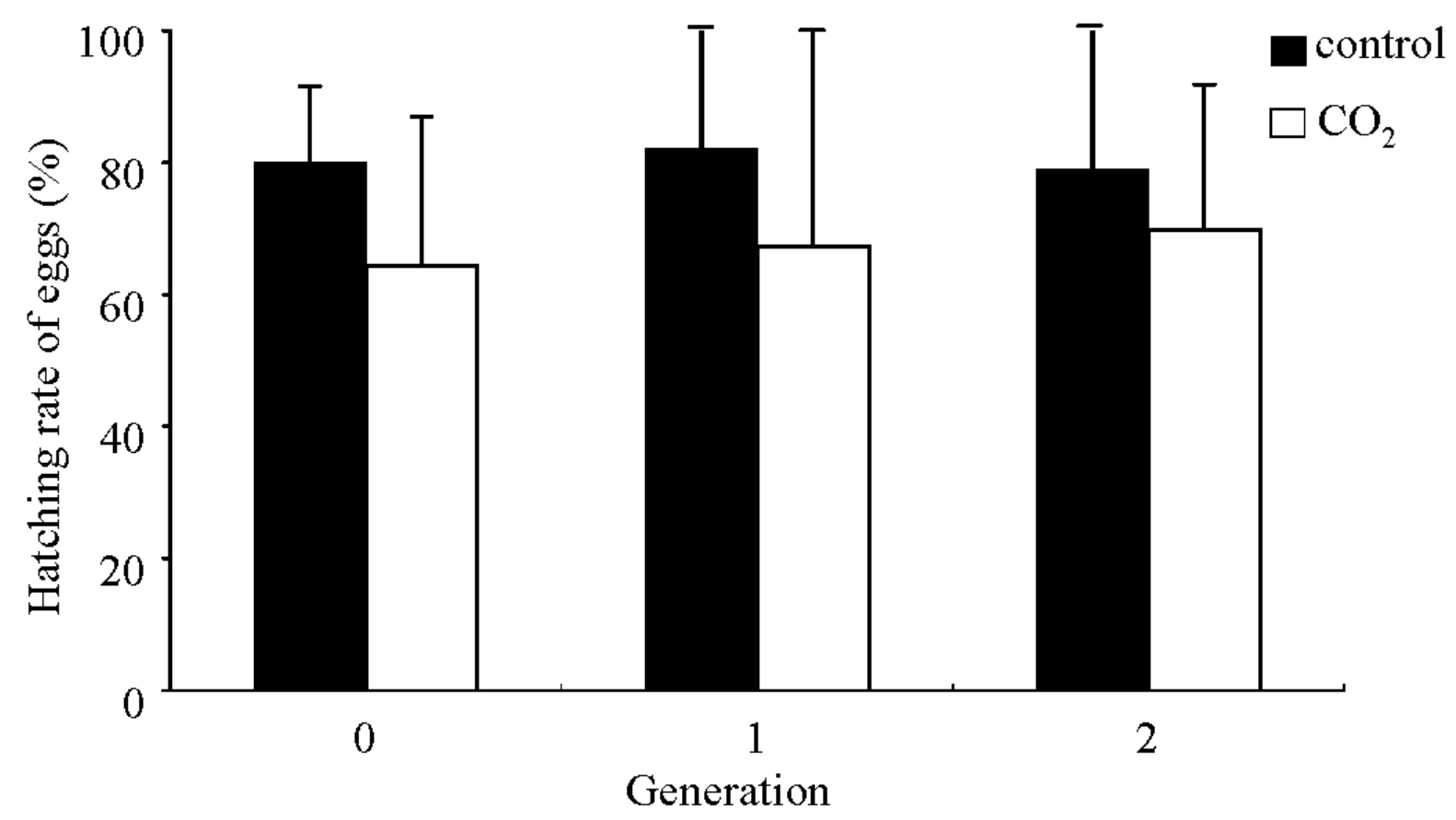

Fig. 5. Hatching rate of eggs produced by the female Acartia tsuensis of generations 0 , 1 and 2. There was a significant difference in the hatching rate between control and $\mathrm{CO} 2$ groups $(\mathrm{P}<0.05$, ANOVA), although there was no difference when compared separately for each generation ( $t$-test). Error bar $=\mathrm{SD}$. 